\title{
Potential for Growth of Candidatus 'Accumulibacter phosphatis' in an Aerobic Shaking Culture
}

\author{
Toshikazu FUKUSHIMA****, Masataka YANO***, Motoharu ONUKI**, \\ Hiroyasu SATOH**, Takashi MINO** \\ * Department of Environmental Engineering, National Cheng Kung University, Tainan 70101, \\ Taiwan R.O.C. \\ ** Division of Environmental Studies, Graduate School of Frontier Sciences, The University of \\ Tokyo, Chiba 277-8563, Japan \\ *** Abell Bio Clean Corp., Tokyo 124-0025, Japan
}

\begin{abstract}
Candidatus 'Accumulibacter phosphatis' ('Accumulibacter') is known as polyphosphate-accumulating organism found in the enhanced biological phosphorus removal (EBPR) activated sludge processes. 'Accumulibacter' is a yet-to-be isolated bacteria, and the growth of 'Accumulibacter' under aerobic conditions is still unknown. In this study, the potential for growth of 'Accumulibacter' in an aerobic shaking culture was evaluated. Activated sludge samples from a laboratory-scale EBPR reactor were incubated for 48 hours under different conditions $(\mathrm{pH}$, temperature and carbon source), and the multiplication of the 'Accumulibacter' 16S rRNA gene was quantified by using quantitative real-time PCR (polymerase chain reaction). The gene showed statistically significant increase when the carbon source in the medium was glucose, the initial $\mathrm{pH}$ was 10.0 and the temperature was $20^{\circ} \mathrm{C}$ $(\mathrm{p}>0.05, \mathrm{n}=9)$. Results in this study showed that 'Accumulibacter' most probably has the potential to grow in an aerobic shaking culture. The obtained results are desired to provide a hint for the successful isolation of 'Accumulibacter'.
\end{abstract}

Keywords: aerobic shaking culture, Candidatus 'Accumulibacter phosphatis', enhanced biological phosphorus removal.

\section{INTRODUCTION}

Candidatus 'Accumulibacter phosphatis' ('Accumulibacter') is currently thought to be the most relevant polyphosphate-accumulating organism in the enhanced biological phosphorus removal (EBPR) process (Seviour et al., 2003). 'Accumulibacter' has been identified by culture-independent approaches (Crocetti et al., 2000; Hesselmann et al., 1999), but has not yet been isolated despite tremendous research efforts.

'Accumulibacter' can assimilate organic substrates under both aerobic and anaerobic conditions (Kong et al., 2004) but there have been no reports on the growth of 'Accumulibacter' under circumstances other than sequential anaerobic-aerobic conditions in the EBPR process. Although it is worthwhile to employ such conditions for the isolation of these organisms, the establishment of anaerobic-aerobic culture conditions is technically complicated and difficult. Thus, it would be helpful to investigate whether 'Accumulibacter' can grow under aerobic culture conditions. If so, this may lead to a simpler approach for its isolation.

In this study, we examined the growth potential of 'Accumulibacter' in an aerobic shaking culture. Activated sludge from laboratory-scale EBPR reactor was incubated for

Address correspondence to Toshikazu Fukushima, Department of Environmental Engineering, National Cheng Kung University, Email: toshi@mail.ncku.edu.tw 
48 hours under different conditions $(\mathrm{pH}$, temperature and carbon source). The growth potential was evaluated by using the quantitative real-time PCR (polymerase chain reaction) method.

\section{MATERIALS AND METHODS Activated sludge}

A laboratory-scale sequencing batch reactor (SBR) with a working volume of $10 \mathrm{~L}$ was operated under sequential anaerobic-aerobic conditions for EBPR. The SBR cycle was $6 \mathrm{~h}$ in total, comprising a 0.5 -h feeding phase, a 1.5 -h anaerobic phase, a $2.5-\mathrm{h}$ aerobic phase, a 1-h settling phase, and a 0.5 -h discharge phase. The sludge retention time (SRT) was about 8 days, and the hydraulic retention time (HRT) was about $10 \mathrm{~h}$. The carbon concentration in the feed for each SBR cycle was $83.3 \mathrm{mg} \mathrm{C/L}$, with acetate as the main carbon source. The phosphorus to carbon ratio (wt/wt) was $1: 15.6$. The concentrations of other nutrients in the feed were $7.3 \mathrm{mg} / \mathrm{L} \mathrm{CaCl}_{2}\left(2 \mathrm{H}_{2} \mathrm{O}\right), 75 \mathrm{mg} / \mathrm{L}$ $\mathrm{MgCl}_{2}\left(6 \mathrm{H}_{2} \mathrm{O}\right), 35 \mathrm{mg} / \mathrm{L} \mathrm{KCl}, 14.7 \mathrm{mg} / \mathrm{L} \mathrm{NH}_{4} \mathrm{Cl}, 18 \mathrm{mg} / \mathrm{L}\left(\mathrm{NH}_{4}\right)_{2} \mathrm{SO}_{4}, 15 \mathrm{mg} / \mathrm{L} \mathrm{K}_{2} \mathrm{HPO}_{4}$, $11.7 \mathrm{mg} / \mathrm{L} \mathrm{KH} \mathrm{KHO}_{4}$, and $3.3 \mathrm{mg} / \mathrm{L}$ allylthiourea. The value of $\mathrm{pH}$ was maintained between 7.8 to 8.0 in the feeding, anaerobic and aerobic phases by using $\mathrm{pH}$ controllers (mk-250, Automatic System Research Co., Tokyo, Japan) that dosed 0.5 M of $\mathrm{HCl}$ or $\mathrm{NaOH}$ when the $\mathrm{pH}$ exceeded the setpoint. Seed sludge was obtained from a full-scale domestic wastewater treatment plant.

To monitor the reactor performance, phosphorus $(\mathrm{P})$ contents of the sludge were measured as described previously (Fukushima et al., 2007a).

\section{Aerobic shaking culture}

Activated sludge samples were taken at the end of the aerobic phase. The sludge samples were immediately diluted to $100 \mathrm{mg}($ dry $) / \mathrm{L}$ by the addition of a culture medium. The carbon concentration in diluted samples was $500 \mathrm{mgC} / \mathrm{L}$. The concentrations of other nutrients were $17.6 \mathrm{mg} / \mathrm{L} \quad \mathrm{CaCl}_{2}\left(2 \mathrm{H}_{2} \mathrm{O}\right), 181.6 \mathrm{mg} / \mathrm{L}$ $\mathrm{MgCl}_{2}\left(6 \mathrm{H}_{2} \mathrm{O}\right), 84.0 \mathrm{mg} / \mathrm{L} \mathrm{KCl}, 35.2 \mathrm{mg} / \mathrm{L} \mathrm{NH}_{4} \mathrm{Cl}, 42.2 \mathrm{mg} / \mathrm{L}\left(\mathrm{NH}_{4}\right)_{2} \mathrm{SO}_{4}, 36.0 \mathrm{mg} / \mathrm{L}$ $\mathrm{K}_{2} \mathrm{HPO}_{4}$, and $28.0 \mathrm{mg} / \mathrm{L} \mathrm{KH}_{2} \mathrm{PO}_{4}$. The initial $\mathrm{pH}$ of the culture medium was adjusted to $6.0,7.0,8.0,9.0$, or 10.0 using $0.1 \mathrm{M} \mathrm{HCl}$ or $0.1 \mathrm{M} \mathrm{NaOH}$. Ten milliliters of aliquots of each diluted sample were placed in sterile $50-\mathrm{mL}$ tubes and incubated for $48 \mathrm{~h}$ with shaking at $150 \mathrm{rpm}$. The tubes were capped with silicone-sponge plugs to provide an oxygen supply. Incubations were performed in triplicate for each combination of cultural conditions. Incubations without a carbon source were performed and used as controls.

After incubation, $\mathrm{pH}$ and dissolved oxygen (DO) were monitored. The total volumes of the samples were then centrifuged at $2300 \mathrm{~g}$, and both the supernatant and the sludge pellets were recovered. Volatile fatty acids (VFA) in the supernatant were detected by capillary electrophoresis (CIA, Waters, Milford, MA, USA). Dissolved organic carbon (DOC) was measured by a TOC analyzer (TOC-V, Shimadzu, Kyoto, Japan). These chemical analyses were performed with one representative tube for each incubation.

Culture conditions were investigated in the following order: (I) $\mathrm{pH}$, (II) temperature and (III) carbon source. The conditions for experiments (II) and (III) were based on the 
optimal conditions from the previous experiment. For the $\mathrm{pH}$ experiment (I), the activated sludge was supplied with glucose $(500 \mathrm{mgC} / \mathrm{L})$ and incubated at $20{ }^{\circ} \mathrm{C}$, with initial $\mathrm{pH}$ values of $6.0,7.0,8.0,9.0$, or 10.0 . For the temperature experiment (II), the activated sludge was supplied with glucose $(500 \mathrm{mgC} / \mathrm{L})$ and incubated at 10, 15, 20, 24, 30 , or $37^{\circ} \mathrm{C}$, with an initial $\mathrm{pH}$ of 10.0 . For the carbon source experiment (III), glucose, acetate, propionate, or lactate was supplied to the sludge at $500 \mathrm{mgC} / \mathrm{L}$ with an initial $\mathrm{pH}$ of 10.0 and temperature at $20^{\circ} \mathrm{C}$.

\section{Quantification of 'Accumulibacter' 16S rRNA gene}

DNA was extracted from the sludge samples using the MORA-EXTRACT kit (AMR Inc., Gifu, Japan). The DNA concentration was determined with a NanoDrop ND-1000 spectrophotometer (Nanodrop Technologies, Wilmington, DE, USA).

A LightCycler (Roche Diagnostics, Mannheim, Germany) was employed for the quantitative real-time PCR for the 16S rRNA genes of 'Accumulibacter'. The PCR conditions were the same as those described previously (Fukushima et al., 2007b) except for the annealing step. To avoid unspecific amplification, annealing condition was changed to $66^{\circ} \mathrm{C}$ for $15 \mathrm{~s}$. The final reaction mixture of $20 \mu \mathrm{L}$ contained: $1.0 \mathrm{U}$ KOD-plus DNA polymerase (Toyobo, Tokyo, Japan), $1 \times$ PCR buffer, $0.3 \mu \mathrm{M}$ (each) primer, $0.2 \mathrm{mM}$ (each) dNTP, $1 \mathrm{mM} \mathrm{MgSO}_{4}, 25 \mu \mathrm{g} / \mu \mathrm{L}$ BSA (Promega, Madison, WI, USA), $25 \mathrm{~nL} / \mu \mathrm{L}$ DMSO (Wako, Tokyo, Japan), $200 \mathrm{pL} / \mu \mathrm{L}$ SYBR Green I (Invitrogen, Carlsbad, CA, USA), and template DNA (or sterilized distilled water as a negative control). The 'Accumulibacter'-specific primers PAO651f (5'-CTG GAG TTT GGC AGA GGG-3') and PAO846r (5'-GTT AGC TAC GGC ACT AAA AGG-3') were used. The DNA extracted from the samples $(5 \mathrm{ng})$ or $1.0 \times 10^{3}$ to $1.0 \times 10^{7}$ copies of quantitative standard DNA were used as the template DNA. Cycling conditions included a pre-incubation step for $5 \mathrm{~min}$ at $94{ }^{\circ} \mathrm{C}$, followed by 35 cycles of $94{ }^{\circ} \mathrm{C}$ for $15 \mathrm{~s}, 66{ }^{\circ} \mathrm{C}$ for $15 \mathrm{~s}$, and $68^{\circ} \mathrm{C}$ for $15 \mathrm{~s}$. Specificity was evaluated from the analysis of the melting curve and the sequencing analysis of the PCR products.

The copy number of the 'Accumulibacter' 16S rRNA gene in the tube was calculated by using equation (1). The multiplication of 'Accumulibacter' 16S rRNA gene in incubation was calculated by dividing the copy number in the tube after incubation by the initial copy number.

copy number of the 'Accumulibacter' $16 \mathrm{~S}$ rRNA gene in the tube $=$

(DNA amount in the tube $) \times($ copy number in the template DNA) $/ 5$

\section{Reproducibility test}

Reproducibility of the increase in the 'Accumulibacter' 16S rRNA gene was evaluated using a $t$-test (Excel 2002, Microsoft, Redmond, WA, USA), when the activated sludge was supplied with glucose and incubated at $20{ }^{\circ} \mathrm{C}$ at an initial $\mathrm{pH}$ of 10.0 . To confirm the reproducibility, nine replicates of the quantification results were obtained from the three incubation experiments (i.e., incubations in each experiment were performed in triplicate) by using different activated sludge.

Reproducibility of DNA extraction and quantitative real-time PCR was also tested with six replicates. Variance was shown as the coefficient of variation based on the 
calculated copy number.

\section{RESULTS AND DISCUSSION}

\section{Aerobic shaking culture under different conditions}

$\mathrm{P}$ contents in the sludge samples used for aerobic shaking culture, ranged from 3.7 to $10.4 \%$.

Table 1 presents the $\mathrm{pH}$ results. Except for the control, the value of $\mathrm{pH}$ decreased noticeably during incubation. Incubation at an initial $\mathrm{pH}$ of 10.0 produced the largest increase in the 'Accumulibacter' 16S rRNA gene, thus subsequent experiments were conducted with an initial $\mathrm{pH}$ of 10.0.

Table 2 shows the temperature results. Incubation at $20{ }^{\circ} \mathrm{C}$ produced the largest increase in the 'Accumulibacter' $16 \mathrm{~S}$ rRNA gene.

Carbon source results are presented in Table 3. Increase of the 'Accumulibacter' 16S rRNA gene was observed only when glucose was fed. Acetate and propionate, which are generally thought to be utilized by 'Accumulibacter' (Seviour et al., 2008), were ineffective under our study conditions.

When we supplied activated sludge with glucose and incubated it at $20^{\circ} \mathrm{C}$ with an initial $\mathrm{pH}$ of 10.0 , we detected 10 to $20 \mathrm{mgC} / \mathrm{L}$ of acetate and propionate after incubation, even though the DO concentrations in each incubation ranged between 2 and $4 \mathrm{mg} / \mathrm{L}$. The $\mathrm{pH}$ in the samples decreased to 6 .

Table 1 - Different initial $\mathrm{pH}$ conditions at $20^{\circ} \mathrm{C}$ and fed with glucose.

\begin{tabular}{cccccc}
\hline \multirow{2}{*}{$\begin{array}{c}\text { initial } \\
\mathrm{pH}\end{array}$} & final $\mathrm{pH}$ & $\begin{array}{c}\text { Carbon } \\
\text { concentration } \\
\text { after incubation }\end{array}$ & $\begin{array}{c}\text { Copies of 'Accumulibacter' } \\
\text { 16S rRNA gene }\left(10^{8} \text { copy/tube }\right)\end{array}$ & $\begin{array}{c}\text { 48-hr incubation/ } \\
\text { inoculum ratio } \pm\end{array}$ \\
\cline { 4 - 5 } & & 113 & & $2.80 \pm 0.07$ & $0.71 \pm 0.02$ \\
6.0 & 3.1 & 97 & & $4.33 \pm 0.90$ & $1.10 \pm 0.23$ \\
7.0 & 3.2 & 93 & $3.77 \pm 0.83$ & $0.95 \pm 0.21$ \\
8.0 & 3.4 & 3.95 & $5.59 \pm 1.21$ & $1.41 \pm 0.31$ \\
9.0 & 3.9 & 194 & & $6.76 \pm 2.73$ & $1.71 \pm 0.69$ \\
10.0 & 6.0 & 219 & $3.41 \pm 0.90$ & $0.86 \pm 0.23$ \\
\hline
\end{tabular}

${ }^{1}$ Activated sludge sample was taken before inoculation into tubes.

${ }^{2}$ Copies of 'Accumulibacter' 16S rRNA gene in activated sludge sample after 48-hr culture divided by those in activated sludge before culture.

${ }^{3}$ Carbon sources were not fed and incubated with an initial of $\mathrm{pH}$ 8.0. 
Table 2 - Different temperatures (A: 10,15 and $20^{\circ} \mathrm{C}$; B: 24,30 and $37^{\circ} \mathrm{C}$ ) with an initial $\mathrm{pH}$ of 10.0 and fed with glucose.

A

\begin{tabular}{cccccc}
\hline \multirow{2}{*}{$\begin{array}{c}\text { Temperature } \\
\left({ }^{\circ} \mathrm{C}\right)\end{array}$} & $\begin{array}{c}\text { Carbon } \\
\text { concentration }\end{array}$ & \multicolumn{2}{c}{$\begin{array}{c}\text { Copies of 'Accumulibacter' } \\
\text { after incubation }\end{array}$} & before & $\begin{array}{c}\text { 48-hr incubation/ } \\
\text { inoculum ratio } \pm\end{array}$ \\
\cline { 3 - 4 } & 459 & & after incubation \pm SD & SD $^{2}$ \\
\hline 10 & 440 & $1.59 \pm 1.18$ & $0.84 \pm 0.62$ \\
15 & 401 & & $2.68 \pm 1.90$ & $1.41 \pm 1.00$ \\
20 & - & & $2.89 \pm 1.60$ & $1.52 \pm 0.84$ \\
control $^{3}$ & & & $2.27 \pm 0.70$ & \\
\hline
\end{tabular}

${ }^{1}$ Activated sludge sample was taken before inoculation into tubes.

${ }^{2}$ Copies of 'Accumulibacter' 16S rRNA gene in activated sludge sample after 48-hr culture divided by those in activated sludge before culture.

${ }^{3}$ Carbon sources were not fed and incubated at $20{ }^{\circ} \mathrm{C}$.

\begin{tabular}{|c|c|c|c|c|}
\hline \multirow{2}{*}{$\begin{array}{c}\text { Temperature } \\
\left({ }^{\circ} \mathrm{C}\right)\end{array}$} & \multirow{2}{*}{$\begin{array}{c}\text { Carbon } \\
\text { concentration } \\
\text { after incubation }\end{array}$} & $\begin{array}{l}\text { Copies of 'A } \\
\text { 16S rRNA gen }\end{array}$ & $\begin{array}{l}\text { Accumulibacter' } \\
\text { ee }\left(10^{8} \text { copy/tube }\right)\end{array}$ & \multirow{2}{*}{$\begin{array}{c}\text { 48-hr incubation/ } \\
\text { inoculum ratio } \pm \\
\mathrm{SD}^{2}\end{array}$} \\
\hline & & before incubation $^{1}$ & after incubation \pm SD & \\
\hline 24 & 192 & \multirow{4}{*}{8.85} & $6.56 \pm 0.35$ & $0.74 \pm 0.04$ \\
\hline 30 & 101 & & $3.24 \pm 0.43$ & $0.37 \pm 0.05$ \\
\hline 37 & 54 & & $1.69 \pm 0.29$ & $0.19 \pm 0.03$ \\
\hline control $^{3}$ & - & & $7.86 \pm 0.46$ & $0.89 \pm 0.05$ \\
\hline
\end{tabular}

${ }^{1}$ Activated sludge sample was taken before inoculation into tubes.

${ }^{2}$ Copies of 'Accumulibacter' 16S rRNA gene in activated sludge sample after 48-hr culture divided by those in activated sludge before culture.

${ }^{3}$ Carbon sources were not fed and incubated at $24{ }^{\circ} \mathrm{C}$.

Table 3 - Different carbon sources with an initial $\mathrm{pH}$ of 10.0 and temperature at $20^{\circ} \mathrm{C}$.

\begin{tabular}{|c|c|c|c|c|}
\hline \multirow{2}{*}{$\begin{array}{l}\text { Carbon } \\
\text { Source }\end{array}$} & \multirow{2}{*}{$\begin{array}{c}\text { Carbon } \\
\text { concentration } \\
\text { after incubation }\end{array}$} & \multicolumn{2}{|c|}{$\begin{array}{c}\text { Copies of 'Accumulibacter' } \\
\text { 16S rRNA gene }\left(10^{8} \text { copy/tube }\right)\end{array}$} & \multirow{2}{*}{$\begin{array}{l}\text { 48-hr incubation/ } \\
\text { inoculum ratio } \pm \\
\mathrm{SD}^{2}\end{array}$} \\
\hline & & before incubation $^{1}$ & after incubation \pm SD & \\
\hline Glucose & 365 & & $7.10 \pm 0.72$ & $1.16 \pm 0.12$ \\
\hline Acetate & 228 & & $5.43 \pm 1.76$ & $0.89 \pm 0.29$ \\
\hline Propionate & 334 & 6.10 & $2.23 \pm 0.28$ & $0.37 \pm 0.05$ \\
\hline Lactate & 258 & & $3.54 \pm 1.24$ & $0.58 \pm 0.20$ \\
\hline control $^{3}$ & - & & $5.60 \pm 0.75$ & $0.92 \pm 0.12$ \\
\hline
\end{tabular}

${ }^{1}$ Activated sludge sample was taken before inoculation into tubes.

${ }^{2}$ Copies of 'Accumulibacter' 16S rRNA gene in activated sludge sample after 48-hr culture divided by those in activated sludge before culture.

${ }^{3}$ Carbon sources were not fed. 


\section{Reproducibility test}

We confirmed the reproducibility of the increase in the 'Accumulibacter' 16S rRNA gene, when we supplied activated sludge with glucose and incubated it at $20{ }^{\circ} \mathrm{C}$ with an initial $\mathrm{pH}$ of 10.0. The copy numbers of the 'Accumulibacter' 16S rRNA gene showed a statistically significant increase $(p<0.05, n=9$ ), with a mean multiple of 1.47 (min 0.98 , max 2.50).

Reproducibility of the sample preparation procedure comprising of DNA extraction and quantitative real-time PCR, was determined to confirm the significance of experimental error. Coefficient of variation was $15 \%$ for the calculated copy numbers $(n=6)$. Melting curve analysis and sequencing analysis were performed using DNA extract from sludge sample which was incubated with glucose at $20{ }^{\circ} \mathrm{C}$ with an initial $\mathrm{pH}$ of 10.0. We confirmed the absence of unspecific peaks in melting curve. Sequence of PCR product was related to 'Accumulibacter'. We did not observe any contaminant peaks in the results of the sequence. These results also supported statistically significant increase of 'Accumulibacter' gene due to their growth.

\section{Growth potential of 'Accumulibacter' in an aerobic shaking culture}

The copy numbers of the 'Accumulibacter' 16S rRNA gene showed a statistically significant increase $(p<0.05, n=9)$ when the activated sludge samples were incubated with glucose at an initial $\mathrm{pH}$ of 10.0 and a temperature of $20^{\circ} \mathrm{C}$. Although the increased copy numbers of the $16 \mathrm{~S}$ rRNA gene do not necessarily indicate an increase in the rate of cell division, they do show that DNA synthesis by 'Accumulibacter' has increased.

The carbon utilization pattern observed in this study does not agree with that reported by Kong et al. (2004). In the latter study, microautoradiography combined with fluorescence in situ hybridization revealed that 'Accumulibacter' assimilated acetate and propionate, but not glucose, under aerobic conditions. This is the opposite of our results. However, in the study by Kong et al. (2004), substrate assimilation was investigated by using 36 to $72 \mathrm{mgC} / \mathrm{L}$ of acetate, 18 to $54 \mathrm{mgC} / \mathrm{L}$ of propionate, or a combination of the two. In our incubations fed with $500 \mathrm{mgC} / \mathrm{L}$ of glucose, 10 to 20 $\mathrm{mgC} / \mathrm{L}$ of acetate and propionate were detected after $48 \mathrm{~h}$ of incubation. Thus, our observations and those of Kong et al. (2004) may be suggesting that 'Accumulibacter' can grow by assimilating low concentrations of acetate and propionate aerobically, but cannot grow when they are supplied with $500 \mathrm{mgC} / \mathrm{L}$ of acetate or propionate because the carbon concentration is too high.

Therefore, our batch experiments might indirectly evaluate the growth of 'Accumulibacter', because its growth depends on the metabolites of other bacteria. Although our results could show significant increase of 'Accumulibacter' $16 \mathrm{~S}$ rRNA gene under the aerobic shaking cultivation, further experiments are required to determine the growth characteristics of 'Accumulibacter' under aerobic condition.

\section{CONCLUSIONS}

In this study, we observed the increase of $16 \mathrm{~S}$ rRNA gene concentration of 'Accumulibacter' in aerobic shaking cultures with glucose as the carbon source with an initial $\mathrm{pH}$ of 10.0 and temperature set at $20^{\circ} \mathrm{C}$. The increase of $16 \mathrm{~S}$ rRNA gene was 
statistically significant. Our results showed that 'Accumulibacter' most probably has the potential to grow in an aerobic shaking culture. We hope that these results will provide a hint for the successful isolation of 'Accumulibacter'.

\section{ACKNOWLEDGEMENT}

This work was supported by the Japan Society for the Promotion of Science (JSPS) as a Grant-in-Aid for Scientific Research (A) 19206057 and as JSPS Fellowship 19-5025.

\section{REFERENCES}

Crocetti G. R., Hugenholtz P., Keller J. and Blackall L. L. (2000). Identification of polyphosphate-accumulating organisms and design of 16S rRNA-directed probes for their detection and quantitation., Appl. Environ. Microbiol., 66, 1175-1182.

Fukushima T., Uda N., Okamoto M., Onuki M., Satoh H. and Mino T. (2007a). Abundance of Candidatus 'Accumulibacter phosphatis' in enhanced biological phosphorus removal activated sludge acclimatized with different carbon sources. Microbes and Environ., 22, 346-354..

Fukushima T., Uda N., Onuki M., Satoh H., and Mino T. (2007b). Development of the quantitative PCR method for Candidatus 'Accumulibacter phosphatis' and its application to activated sludge., J. Water Environ. Technol., 5, 37-43.

Hesselmann R. P. X., Werlen C., Hahn D., van der Meer J. R., and Zehnder A. J. B. (1999). Enrichment, phylogenetic analysis and detection of a bacterium that performs enhanced biological phosphate removal in activated sludge., Syst. Appl. Microbiol., 22, 454-465.

Kong Y., Nielsen J. L., and Nielsen P. H. (2004). Microautoradiographic study of Rhodocyclus-related polyphosphate-accumulating bacteria in full-scale enhanced biological phosphorus removal plants., Appl. Environ. Microbiol., 70, 5383-5390.

Seviour R. J., and McIlroy S. (2008). The microbiology of phosphorus removal in activated sludge processes - the current state of play., J. Microbiol., 46, 115-124.

Seviour R. J., Mino T., and Onuki M. (2003). The microbiology of biological phosphorus removal in activated sludge systems., FEMS Microbiol. Rev., 27, 99-127. 